\title{
A Review of Resourcing Approaches in Post Disaster Housing Reconstruction
}

\author{
Nour Saleh $^{1}$, Adnan Enshassi ${ }^{1,2 *}$, Matthias Sundermeier ${ }^{1}$ \\ ${ }^{1}$ Institute of Civil Engineering, \\ Technical University of Berlin, Berlin, GERMANY \\ ${ }^{2}$ Department of Civil Engineering, \\ Islamic University of Gaza, Gaza, PALESTINE \\ *Corresponding Author
}

DOI: https://doi.org/10.30880/ijscet.2020.11.03.005

Received 20 November 2019; Accepted 29 April 2020; Available online 30 June 2020

Abstract: In recent years, the occurrence of disasters is on increase and causes heavy human losses and massive destruction especially on housing sector. Post disaster housing reconstruction (PDHR) is a part of the cycle of four disaster management stages: mitigation, preparedness, response; and recovery and reconstruction. Availability of resources is a key factor to a successful PDHR project. This study systematically reviews 94 articles during the period of 2003 and 2019 on different experiences of PDHR. The study reports the various resourcing approaches of PDHR, their strategies, and their advantages and disadvantages. It identifies the critical success factors that led to a successful resourcing approach. The most cited factors reported in this study can be used as a guide to reconstruction practitioner to choose the most appropriate resourcing approach to reconstruct houses after disasters.

Keywords: Resourcing approaches, PDHR, quality, success factors

\section{Introduction}

The occurrence of disasters is on the increase (Alston et al., 2018; Vahanvati \& Mulligan, 2017; Enshassi et al., 2017a; Enshassi \& Shakalaih, 2016). Natural and human induced disasters cause massive destruction, damage and human losses and the victims face the situation of collective suffering and physical and psychological trauma (Carrasco, Ochiai \& Okazaki, 2016; Shafique \& Warren, 2016, Enshassi \& Shatat, 2012). One of the most visible consequences of disasters is the widespread devastation of houses (Brück, d'Errico \& Pietrelli, 2018; He \& Zhuang, 2016; Barakat \& Shaban, 2015). Housing is one of the basic requirements necessary for a standard of living and personal security (Butt \& Butt, 2016). Therefore, housing reconstruction projects is the first priority in many countries in post disasters (Hidayat \& Egbu, 2010). However, PDHR is considered as one of the least successful sectors in terms of implementation (Islam, Kolade \& Kibreab, 2018; Enshassi et al., 2017a). Thus, there is a need to understand what makes it effective to utilize the disaster to be an opportunity to build back better (Fayazi \& Lizarralde, 2019; Vahanvati \& Mulligan, 2017; Vahanvati \& Beza, 2017). One of the key contributory factors to a successful performance of PDHR projects is the availability of resources (Samaddar et al., 2016; Chang et al., 2012a; 2012b). This study reviews the various resourcing approaches and their advantages and disadvantages. It also identifies the factors that affect the choice of resourcing approach and critical factors influencing the success of a resourcing approach.

\section{Resourcing Approaches}


Resourcing calls for an integrated connection with all stakeholders and a cohesive resourcing approach that embraces those actors into an adaptive process for resource provision (Chang et al., 2010). A resourcing approach defines the relationships, roles and responsibilities of stakeholders and activities required to preserve the resource availability in reconstruction (Barenstein \& Pittet, 2007). The type of resourcing approach can be identified in terms of the way and extent to which the stakeholders organize and manage resourcing activities (Chang et al., 2010; Barakat, 2009).

The World Bank defined five types of resourcing of post disaster housing reconstruction approaches including: Owner-Driven Reconstruction (ODR); Cash Approach (CA); Community Driven Reconstruction (CDR); AgencyDriven Reconstruction In-Situ (ADRIS); and Agency-Driven Reconstruction in Relocation Site (ADRRS) (Jha et al., 2010, p. 93). In cash-based approach; owner driven approach; and community driven approach, individuals built their homes with financial and technical assistance from the government and NGOs. On the other hand, houses are reconstructed by a contractor in the contractor driven approach either in-situ or in a relocation site (Arlikatti et al., 2018). Meanwhile, Chang et al. (2010, p. 251) identified four resourcing approaches which are government-driven resourcing; donor-driven resourcing; market-driven resourcing; and owner-driven. This study reviews the resourcing approaches identified by the World Bank which frequently used in post disaster reconstruction and adopted by most of previous researches in post disaster reconstruction (Enshassi et al., 2017a; Thurairajah, 2013; Chang, 2012; Jha et al., 2010). These approaches are: ODR, CBR, CDR, ADRIS and ADRRS. The following sections provide a brief overview of the main features, the advantages, and the disadvantages of each approach:

\subsection{Owner Driven Reconstruction (ODR)}

ODR can be termed as "self-help" or "self-built housing”, (Sharma, 2018; Andrew et al., 2013). Other terms used in ODR are 'community', 'participation', 'engagement' and 'mobilization' (Mulligan, 2015). ODR focused on helping individuals, groups and communities to restore their houses with a combination of financial and technical assistance with regard to material selection and procurement (Bothara et al., 2016; Samaddar et al., 2016; Davis \& Alexander 2015). In other words, ODR approach has three fundamental requirements which are participatory process of decisionmaking; adequate technical support; and adequate financial assistance (International Federal of Red Cross and Red Crescent Societies IFRC, 2010).

ODR allows the affected people to participate in the decision regarding their reconstructed houses: planning activities, building design, area for building, selection of building materials, and which builders to hire (Fayazi \& Lizarralde, 2019; Carrasco \& O’Brien, 2018). In this approach, technical support provided for the affected people includes engineering solutions, e.g. design, quality monitoring and building approvals, technical manuals and nonengineering solutions, e.g. financial management, vocational training and leadership training (Maly, 2018; Wilkinson et al., 2014; Andrew et al., 2013). Technical support can be provided by employing national and international consultants or by establishing partnerships with the private sector or specialist NGOs (Da Silva \& Batchelor, 2010). Financial assistance in ODR can be in cash transfer or material grant. It is given to owners through financial or social institutions or in-hand to the families in stages, depending on the successful completion of the previous stage (Tambe et al., 2018; Aubrey, 2010; Ingirige et al., 2008). The major funding sources in ODR approach are insurance companies, homeowner savings, bank loans and other external assistance such as subsidies and grants from the government and donations from the aid agencies and international aid agencies (Bothara et al., 2016; Andrew et al., 2013).

There is a common misunderstanding about ODR that owners will build their houses by themselves (Jha et al., 2010; Schilderman, 2010; Barenstein, 2006). However, owners may undertake reconstruction of their house by themselves, by employing family labor, a local contractor or local laborers, or by using some combination of these options (Bothara et al., 2016; Aubrey, 2010). Recent examples show that people tend to hire local contractors or laborers for at least part of the work (Sharma, 2018; Jha et al., 2010; Schilderman, 2010). In these situations, owners make choices of materials and designs, and monitor the process with the assistance of the facilitating agencies, while the contractors execute the reconstruction work (Sharma, 2018).

ODR is adopted firstly during PDHR in the 1999 earthquake in Colombia (Lizarralde, 2010) and in 2001 Gujarat earthquake in India (Tambe et al., 2018; Ahmed, 2011). Then, the use of ODR is attracting increasing attention (Tambe et al., 2018; Karunasena \& Rameezdeen, 2010). It was employed as a main strategy after different disasters around the world like the 2003 Bam Earthquake in Iran (Fayazi \& Lizarralde, 2019), the 2004 tsunami in Thailand, Indonesia and Sri Lanka (Leersum \& Arora, 2011), the 2005 earthquake in Kashmir, India (Vahanvati \& Beza, 2017), the 2007 Sidr Cyclone in Bangladesh (Alam, 2010), and the 2008 Bihar Kosi flooding in Nepal (Tambe et al., 2018). Additionally, ODR was used after man-made disasters such as the inter-ethnic violence after the Kenyan elections in December 2007 (Aubrey, 2010).

\subsubsection{Advantages}

ODR approach is considered as the most cost effective approach (Tambe et al., 2018; Santiago et al., 2017; Vahanvati \& Beza, 2017; Danquah, Attippoe \& Ankrah, 2014). The most critical benefit of ODR is that it allows the affected individuals to decide how to rebuild a critical piece of their lives to meet their needs (Samaddar et al., 2016; 
Da Silva \& Batchelor, 2010). Thus, the prioritization of needs and decision-making are in the hands of the affected families which is named as functionality (Danquah, Attippoe \& Ankrah, 2014; Andrew et al., 2013; Ballesteros \& Egana, 2013). Active participation of the affected families in reconstruction is a useful way of restoring a sense of pride and well-being especially in people who have been through a trauma (Fayazi \& Lizarralde, 2019; Da Silva \& Batchelor, 2010; Lyons, 2010; 2009). It helped to establish a growing sense of participants' ownership and identity, self- esteem and self-reliance (Sharma, 2018; Tambe et al., 2018).

One outstanding feature of this approach is equity where the financial grant to each family is the same and families can manage their money wisely (Lankatilleke, 2010). Moreover, the assistance can be adjusted according to the families' needs based on their income, family size, livelihoods, and socio-cultural requirements (Jha et al., 2010). An important strength of ODR is its ability to contain the costs without compromising quality (Lyons, 2009). This approach can reach large numbers of beneficiaries in a short period of time which means that more houses will be reconstructed (Barenstein \& Iyengar, 2010). ODR has a fast reconstruction process (Tambe et al., 2018; Vahanvati \& Beza, 2017; Santiago et al., 2017).

Providing financial and technical support directly to the beneficiaries, coupled with monitoring system by qualified individuals and intense involvement of beneficiaries resulted in a high transparency and accountability (Tambe et al., 2018); which reduces the chances of corruption (Hidellage \& Usoof, 2010). Further, ODR approach allowed the residents to have extensions to their houses in the future for improvements that match their livelihood strategies and conditions based on their needs and resources (Carrasco, Ochiai \& Okazaki, 2016; Karunasena \& Rameezdeen, 2010).

People in ODR tend to utilize the local building materials and methods of construction (Sharma, 2018; Bothara et al., 2016; Alam, 2010). Accordingly, it has the potential to promote the local economies and livelihood (Vahanvati \& Beza, 2017; Ahmed, 2011; Kovács, Matopoulos \& Hayes, 2010). It also helps the owners to adopt their local cultural heritage which preserve the community's cultural identity (Bothara et al., 2016; Lankatilleke, 2010). Therefore, the overall design, layouts and locations will be acceptable to the beneficiaries (Enshassi \& Shakalaih 2016; Lyons, 2009; Ratnayake \& Rameezdeen 2008). All in all, ODR resulted in a high level of beneficiaries' satisfaction of the mechanism process of reconstruction and of their reconstructed houses (Vahanvati \& Beza, 2017; Samaddar et al., 2016; Tafti \& Tomlinson, 2015; Ophiyandri et al., 2013).

\subsubsection{Disadvantages}

Despite the previous mentioned advantages, ODR approach entails some risks and drawbacks that need to be fully understood and taken into account (Fayazi \& Lizarralde, 2019; Barenstein \& Iyengar, 2010; Jha et al., 2010). It is important to recognize that not all beneficiaries may be willing or able to manage the reconstruction process of their houses especially the financial management (Barenstein et al., 2005; Barakat, 2003). The most vulnerable families in particular may not have the capacity to fully participate and manage reconstruction alone (Samaddar et al., 2016; Tafti \& Tomlinson, 2015; Hidellage \& Usoof, 2010; Kovács, Matopoulos \& Hayes, 2010). In addition, fewer community members had the building skills needed to tackle the reconstruction (Enshassi et al 2018; Enshassi et al 2017b, Aubrey, 2010; Barakat, 2003). As the responsibility may prove too demanding and some beneficiaries may withdraw from the process because their time might be better used to generate income (Aubrey, 2010; Barenstein, 2006). Without good standards and qualified individuals in reconstruction process, the quality of reconstruction may be poor (Arroyo, 2015; Jha et al., 2010).

Besides, the absence of a very strict monitoring mechanism in ODR led to beneficiaries' misuse of the funding in other purposes than reconstruction (Alam, 2010; Karunasena \& Rameezdeen, 2010; Kovács, Matopoulos \& Hayes, 2010). Some beneficiaries tend to resell the distributed materials (Barakat, 2003). After a major disaster, the procurement of construction materials may be stressed with excessive demand, and subject to inflation which affect the material prices (Barenstein \& Iyengar, 2010). Accordingly, grant amount given to beneficiaries may not be enough to complete the steps and they may be forced to bear some additional financial burdens (Tambe et al., 2018; Samaddar et al., 2016; Arslan \& Johnson, 2010; Lyons, 2009).

\subsection{Cash Based Reconstruction Approach (CBR)}

CBR approach is a subset of owner driven reconstruction approach (Schilderman, 2010). It provides unconditional financial assistance without technical support for housing reconstruction (Enshassi et al., 2017a; Carrasco, Ochiai \& Okazaki, 2016; Danquah, Attippoe \& Ankrah, 2014). Davis \& Alexander (2015) stated that this approach replaces inkind assistance with cash distribution. Financial support for reconstruction of damaged houses is provided by aid agencies in terms of cash grants or cash transfer (Chang, 2012). Cash based transfers can be carried out in many ways; for example, vouchers, loans, conditional transfers (Karunasena \& Rameezdeen, 2010). In CBR, owner procures the construction material through local market mechanisms using the provided fund and takes up the construction (Tambe et al., 2018; Bessant, 2015).

CBR is appropriate when disasters have a relatively limited impact (Bessant, 2015; Barenstein, 2012; Jha et al., 2010). It can be also adopted, when the area is inaccessible and the facilitating staff cannot reach the area to provide 
technical assistance (IFRC, 2010). CBR approach is the best choice when local building capacity and financial support are adequate (Barenstein \& Iyenger, 2010; Jha et al., 2010). This approach may give affected people the choice to use the assistance based on their own priorities, which may not necessarily be housing (Barenstein, 2012). CBR was adopted after the 2004 Santa Fe floods in Argentina (Danquah, Attippoe \& Ankrah, 2014; Jha et al., 2010), 2005 earthquake in Pakistan (Fayazi \& Lizarralde, 2019); and following the Kashmir floods of 2014 (Tambe et al., 2018).

\subsubsection{Advantages}

CBR approach depends on conditional financial transfer in installments which reduces the risk of beneficiaries' misuse and misappropriation of the assistance based on their own priorities (Barenstein, 2012; Karunasena \& Rameezdeen, 2010). However, this approach allows the affected people to employ the financial assistance based on their own priorities, which may not necessarily be housing (Fayazi \& Lizarralde, 2019; Danquah, Attippoe \& Ankrah, 2014). Accordingly, it leads to an overall strengthening of people's livelihoods assets and a reduction of their vulnerability (Barenstein \& Iyenger, 2010; Schilderman, 2010). In CBR approach, beneficiaries tend to use local building materials and local labor, which positively affect the local livelihoods (Jha et al., 2010; Karunasena \& Rameezdeen, 2010). In some cases, it is considered as the most cost effective approach due to reduced transaction costs; and rapid delivery of aid to households (Tambe et al., 2018; Barenstein, 2012, Jha et al., 2010). CBR decreases the dependency on technical reconstruction assistants and gives residents additional freedom to make decisions (Fayazi \& Lizarralde, 2019, Davis \& Alexander, 2015). Involvement of beneficiaries helps them to be empowered and increase their sense of ownership and identity (Barenstein \& Iyenger, 2010, Karunasena \& Rameezdeen, 2010, Kovács, Matopoulos \& Hayes, 2010). In CBR, the assistance can be adjusted to household's income, family size, livelihoods, sociocultural requirements, etc. (Jha et al., 2010).

\subsubsection{Disadvantages}

Literature also pointed to a number of potential disadvantages of CBR approach (Fayazi \& Lizarralde, 2019; Barenstein \& Iyenger, 2010). Cash grants handed out after disasters might be not sufficient for reconstruction which bear the owner to afford some fund to complete the reconstruction process (Tambe et al., 2018; Barenstein \& Iyenger, 2010). Moreover, the provided funds to the affected people may be misused in other purposes than reconstruction (Enshassi et al., 2017a; Karunasena \& Rameezdeen, 2010). In CBR, vulnerable people may be unable to handle repair and reconstruction without technical assistance (Barenstein, 2012; Barenstein \& Iyenger, 2010; Jha et al., 2010). There is a lack of the opportunity for labor training in CBR to improve their building skills and introduce better techniques, materials and new building technologies (Fayazi \& Lizarralde, 2019; Karunasena \& Rameezdeen, 2010). Therefore, CBR may reproduce pre disaster vulnerabilities instead of development if it is not applied efficiently (Danquah, Attippoe \& Ankrah, 2014).

\subsection{Community Driven Reconstruction (CDR)}

The CDR approach is a grass root approach of the ODR approach (Kovács, Matopoulos \& Hayes, 2010). In CDR, communities protect themselves and their property from disaster instead of relying on external support (Roosli, Nordin \& O'Brien, 2018; Boen, 2008; Chen, Liu \& Chan, 2006). Community in reconstruction projects is defined as "groups of beneficiaries for housing reconstruction in which their houses are affected by a disaster" (Ophiyandri et al., 2013, p. 238). In this approach, the reconstruction process should be through a collective effort (Lankatilleke, 2010); where every family has to participate in the development of their housing and work together to rebuild their housing, lives, and livelihoods (Roosli, Nordin \& O'Brien, 2018, Lankatilleke, 2010). CDR is a post reconstruction approach where people are extensively participated in decision making and managing reconstruction (Carrasco, Ochiai \& Okazaki, 2016; Lu \& Xu, 2014; Omidvar, Zafari \& Derakhshan, 2010). The level of community participation in CDR should be at the level of collaboration or empowerment (Sadiqi, Trigunarsyah \& Coffey, 2016; Ophiyandri, Amaratunga \& Keraminiyage, 2015; 2013).

All provided support in CDR is similar to ODR but financial and/or material assistance is channeled through community organization (Vahanvati, 2017; Carrasco, Ochiai \& Okazaki, 2016; Danquah, Attippoe \& Ankrah, 2014 Jha et al., 2010). The major fund sources in CDR approach are government and aid agencies (Chang, 2012). In some cases, people provided the construction materials themselves (Omidvar, Zafari \& Derakhshan, 2010; Pyles, 2007).

In CDR, community is not only consulted as the beneficiaries, but also has the power to control over the reconstruction phase (Istijono \& Ophiyandri, 2015; Ophiyandri et al., 2013; Ophiyandri, Amaratunga, \& Pathirage, 2010; Omidvar, Zafari \& Derakhshan, 2010). Beneficiaries can be an owner, a supervisor, or even a contractor of their own housing reconstruction project (Jha et al., 2010). The community may be involved in one or more of the roles including managing and supervising the reconstruction, housing design and building materials, production of building materials; and distribution of building materials, or forms of housing assistance (e.g., cash and vouchers) (Roosli, Nordin \& O’Brien, 2018; Samaddar et al., 2016; Lawther, 2009; Dasgupta \& Beard, 2007). CDR does not necessarily involve owners reconstructing their houses themselves but placing the community at the center of the reconstruction 
process with external support provided in the form of building materials, training, finance, technical services and supervision (Da Silva \& Batchelor, 2010; Barenstein, 2006).

CDR approach has risen in the late twentieth century (Bilau \& Witt, 2016; Chen, Liu \& Chan, 2006). It was adopted in the case of housing reconstruction in the manmade disaster in Kosovo in the late 1990s (Kovács, Matopoulos \& Hayes, 2010). A small-scale community participation is taken after the 1999 Duzce earthquake in Turkey (Arslan \& Unlu, 2006). In addition, the housing reconstruction after 2003 Bam earthquake in Iran was using the community approach (Ophiyandri, Amaratunga \& Pathirage,2010). CDR was a successful approach in the reconstruction following the 2001 Gujarat earthquake (Barenstein, 2012), 2004 tsunami in Maldives (Lawther, 2009), the 2008 Wenchuan earthquake ( $\mathrm{Lu} \& \mathrm{Xu}, 2014)$; the 2011 Typhoon Washi in Cagayan de Oro in Philippine (Carrasco, Ochiai \& Okazaki, 2016), following the 2011 Tohoku earthquake in Japan (Bilau, Witt \& Lill, 2015); and after 2015 Nepal earthquake in Kathmandu (Bothara et al., 2016).

\subsubsection{Advantages}

CDR approach allowed owners to have high degree of control over the reconstruction (Samaddar et al., 2016; Istijono \& Ophiyandri, 2015; Lawther, 2009). It based mainly on the beneficiary participation and empowerment (Kingham, Dionisio \& Newman, 2016, Istijono \& Ophiyandri, 2015, Kovács, Matopoulos \& Hayes, 2010, Lawther, 2009, Leitmann, 2007). Samaddar et al. (2016) stated that the CDR is the most effective approach and recorded the highest level of public participation. Empowering the affected communities to participate in reconstruction enable them to articulate their needs (Bothara et al., 2016; Sadiqi, Trigunarsyah \& Coffey, 2016; Ophiyandri, Amaratunga \& Keraminiyage, 2015). The house owners are free to choose the designs of their houses based on their culture, customs and local lifestyles which promote their cultural identity (Sitorus, 2017, Kingham, Dionisio \& Newman, 2016). Ophiyandri, Amaratunga \& Keraminiyage (2015) demonstrated that because the community build their own house, they will build it to the best of their abilities, follow the building code, and they will not be cheating. Accordingly, the quality of the reconstruction will be increased (Samaddar et al., 2016; Ophiyandri, Amaratunga \& Keraminiyage, 2015; 2010).

Community's involvement in the reconstruction process resulted in a high transparency and accountability (Enshassi et al 2019; Istijono \& Ophiyandri, 2015; Daly \& Brassard, 2011). Thus, CDR can minimize corruption practices (Ophiyandri, Amaratunga \& Keraminiyage, 2015). Public participation in CDR promotes the democracy in which every citizen should have a say in all stages of the reconstruction of their houses (Kingham, Dionisio \& Newman, 2016; Dasgupta \& Beard, 2007). It also reduces the marginalization among beneficiaries because every member of the community can participate in the reconstruction process (Ophiyandri, Amaratunga \& Pathirage,2010). CDR strengthens the local capacities for collective action and make the beneficiaries more unite (Roosli, Nordin \& O'Brien, 2018; Samaddar et al., 2016). Communities that are involved and empowered are more likely to present better social wellbeing, and a stronger sense of resilience and governance (Kingham, Dionisio \& Newman, 2016). CDR has proven an efficient means to intensify the feeling of ownership and pride among beneficiaries (Ophiyandri, Amaratunga \& Keraminiyage, 2015; 2010; Lawther, 2009).

CDR based on the local resources including the labor and materials (Istijono \& Ophiyandri, 2015; Chang et al., 2012b, 2010; Kovács, Matopoulos \& Hayes, 2010); which will positively affect the local economic development (Roosli, Nordin \& O’Brien, 2018; Lawther, 2009; Chen, Liu \& Chan, 2006). CDR is a cost effective approach as the transportation cost of local materials is very low and the cost of local labor is also more cost efficient (Samaddar et al., 2016; Lawther, 2009). CDR approach is known with its flexibility as the modifications to house designs is possible, especially the incorporation of extensions in the future (Da Silva \& Batchelor, 2010, Dasgupta \& Beard, 2007, Pyles, 2007).

\subsubsection{Disadvantages}

Although CDR approach is empowering, it still has a number of disadvantages (Sadiqi, Trigunarsyah \& Coffey, 2016; Barenstein, 2012; Ophiyandri, Amaratunga \& Pathirage,2010). There is lack of understanding of the community participation approach in housing reconstruction. The effectiveness of reconstruction mainly depends on community participation in the implementation of reconstruction program (Kovács, Matopoulos \& Hayes, 2010). If CDR is not applied effectively, it can lead to cost overrun, delays in delivery, quality degradation and dissatisfaction (Ophiyandri et al., 2013; Barenstein, 2012; Lawther, 2009). In the implementation of real community participation, many activities during preconstruction stage takes time such as forming a community organization (Ophiyandri, Amaratunga \& Keraminiyage, 2015; 2013); while, post disaster reconstruction requires to be completed in the shortest time (Ophiyandri, Amaratunga \& Keraminiyage, 2015; Lawther, 2009). The level of community control on PDR will mainly depend on the community capacity (Roosli, Nordin \& O’Brien, 2018; Ophiyandri, Amaratunga \& Keraminiyage, 2015; 2013). Community participation in PDR required many and varied skills (Roosli, Nordin \& O'Brien, 2018; Lawther, 2009; Chen, Liu \& Chan, 2006). Furthermore, keeping a community continuously engaged in a project is quite challenging. Since, local community is initially very interested, but after a certain period loses interest and withdraws from the project (Samaddar et al., 2016, Chen, Liu \& Chan, 2006). 


\subsection{Agency Driven Reconstruction (ADR)}

ADR approach is equivalent to donor driven reconstruction and contractor driven reconstruction approach (Barenstein, 2015; Andrew et al., 2013; Lyons, 2009). In this approach, the agency could be a donor (of private, government or non-government sectors) either local or international (Santiago et al., 2017, Barenstein, 2015, Ophiyandri, Amaratunga \& Keraminiyage, 2015). In ADR approach, housing reconstruction is entirely handled by the agency concerned from inception to handing over of housing units to recipients (Karunasena \& Rameezdeen, 2010). The agency effectively took on the role of developer, acting on behalf of the communities to develop a design, appoint a contractor and oversee delivery (Da Silva \& Batchelor, 2010). In this approach, the agency hires a professional construction company to design and build new houses (Bilau \& Witt, 2016; Barenstein, 2015; Hsu et al., 2015); where the contractor is not accountable to the community (Danquah, Attippoe \& Ankrah, 2014, Barenstein, 2012), but to the agency (Jha et al., 2010).

Regarding the financial costs, the entire reconstruction costs in ADR approach is covered by the national and international NGOs (Samaddar et al., 2016; Barenstein, 2012). Designs, materials and expertise are imported from outside the community in this approach (Danquah, Attippoe \& Ankrah, 2014; Barenstein, 2006; Barakat, 2003). It may be the best solution when the affected communities lack the building skills (Da Silva \& Batchelor, 2010; Barenstein, 2006). The reconstruction in agency driven approach takes place in-situ (ADRIS); or in relocation site (ADRRS) (Santiago et al., 2017; Bilau \& Witt, 2016; Hsu et al., 2015). The difference between in situ and in relocation site approaches is the place of housing reconstruction (Thurairajah, 2013). ADRRS approach includes resettlement of communities outside the buffer zone (a no-build zone) to safer zones (Bilau \& Witt, 2016; Karunasena \& Rameezdeen, 2010). Barenstein (2006) concluded that agencies tend to prefer the ADRRS to construct new villages on clear ground. However, public pressure prefers rebuilding on existing sites (in situ). After the 1993 earthquake in Maharashtra, ADRIS was adopted. In which, a large NGO with a close association to a construction company reconstructed five villages (Barenstein et al., 2005). It was adopted again after the 2001 Gujarat, India, earthquake (Jha et al., 2010; Barenstein, 2006). Moreover, many private voluntary organizations adopted ADRIS in Tamil Nadu, India, following the 2004 Indian Ocean tsunami (Barenstein, 2012; Jha et al., 2010).

On the other hand, ADRRS approach was adopted to reconstruct houses in Turkey after the 1999 Marmara earthquake (Bilau \& Witt, 2016). It was also used following Typhoon Morakot in southern Taiwan (Hsu et al., 2015). In post 2001 Gujarat earthquake, ADRRS was adopted by International NGOs and national private companies (Samaddar et al., 2016; Danquah, Attippoe \& Ankrah, 2014). In Sri Lanka and India, following the tsunami of 2004, some reconstruction was carried out with ADRRS approach (Danquah, Attippoe \& Ankrah, 2014; Ahmed, 2011; Lyons, 2009). Furthermore, the context for post disaster housing provision in the 2012 Typhoon Washi in the Philippines is mainly based ADRRS (Carrasco, Ochiai \& Okazaki, 2018; Carrasco \& O'Brien, 2018). The following sections clarify the advantages and disadvantages of ADRIS and ADRRS:

\subsubsection{Advantages of Agency driven reconstruction in situ (ADRIS)}

The main advantage of this approach is that the communities are not moved to new location and displaced (Santiago et al., 2017; Samaddar et al., 2016; Bilau \& Witt, 2016). Therefore, land acquisition is not required. ADRIS allows the household to know where its house will be located (Jha et al., 2010). Hence, people were satisfied with their houses' location and situation after disaster (Fayazi \& Lizarralde, 2019). The reconstruction in the pre disaster location allows people to have some degree of control over the reconstruction (Danquah, Attippoe \& Ankrah, 2014; Barenstein, 2012). House owners may be participated in some tasks; such as curing concrete (Jha et al., 2010). During the reconstruction process, householders may suggest or modify the design (Danquah, Attippoe \& Ankrah, 2014; Barenstein, 2012; Jha et al., 2010). However, if housing designs are standardized, it may be difficult to modify them (Jha et al., 2010). In this case, ADRIS approach may give people the option to choose between different designs (Barenstein, 2006). Above that, using construction companies allows for rapid reconstruction with standard specifications, using staff with technical expertise and specialist skills (Bilau \& Witt, 2016; Da Silva \& Batchelor, 2010).

\subsubsection{Disadvantages of Agency driven reconstruction in situ (ADRIS)}

This approach depends on contracting construction companies who tend to adopt a 'one-size-fits-all' design (Barenstein et al., 2005). In other words, the owners' needs are not articulated and diversity within the community is not taken into consideration (Jha et al., 2010; Barenstein et al., 2005). Accordingly, the houses built by contractors are inadequate from a socio- cultural point of view (Barenstein \& Iyenger, 2010; Jha et al., 2010). Moreover, ADRIS reported high level of corruption by contractors (Jha et al., 2010). Since, the main goal of contractors is to maximize profits (Jha et al., 2010; Barenstein, 2006), which resulted in poor quality of material and reconstruction that affect the owners' satisfaction (Barenstein, 2012; Jha et al., 2010). Poor quality of reconstructed houses using ADRIS led several people not to trust the safety of the house which resulted in reducing the occupancy rate (Barenstein, 2006). Building in 
the pre disaster location required clearing the land of houses before starting construction (Jha et al., 2010; Barenstein, 2006). Accordingly, ADRIS led to massive demolition of the historical villages and houses that are culturally appropriate and easily repairable (Barenstein \& Iyenger, 2010).

\subsubsection{Advantages of Agency driven reconstruction in relocated sites (ADRRS)}

In this approach, agencies have more control over the reconstruction process and the reconstruction project has a higher level of visibility (Hsu et al., 2015; Andrew et al., 2013). The agencies favor this approach since it is the easier way to replace the damaged houses (Tambe et al., 2018; Bilau \& Witt, 2016; Samaddar et al., 2016). This returned back to hiring professional construction companies, which constructed relatively quickly using staff with technical expertise, specialist skills and standard specifications (Carrasco, Ochiai \& Okazaki, 2016; Da Silva \& Batchelor, 2010). ADRRS include resettlement of communities to safer zones (Bilau \& Witt, 2016; Karunasena \& Rameezdeen, 2010). Therefore, there is no need to remove rubbles, since the construction is on a clear site (Jha et al., 2010; Barenstein, 2006, Barenstein et al., 2005). ADRRS provides the survivors a full village reconstruction included infrastructure such as roads, schools, a community hall, a water supply system and drainage canals (Barenstein, 2006). Danquah et al. (2014) concluded that ADRRS approach promotes communication within the neighborhood and promotes community gathering. It also protects the vulnerable communities that would receive no financial assistance or technical support (Oliver-Smith \& De Sherbinin, 2014).

\subsubsection{Disadvantages of Agency-driven reconstruction in relocated sites (ADRRS)}

ADRRS approach has been described as "centralized and exclusionary" (Andrew et al., 2013; Ahmed, 2011). Decision making is managed and controlled by governmental and non-governmental agencies (Danquah, Attippoe \& Ankrah, 2014; Barenstein, 2012). ADRRS approach gives the lowest opportunity to the local communities to involve and participate in reconstruction process (Carrasco \& O’Brien, 2018; Samaddar et al., 2016; Bilau, Witt \& Lill, 2015). In this approach, the agencies do not ask their beneficiaries to design their relocated village or to decide the relocation site (Carrasco, Ochiai \& Okazaki, 2016; Barenstein, 2015). This will affect the capacity and knowledge of the affected community; and reduce their disaster awareness level (e.g. construction skills, decision making ability) (Sina et al., 2018, Schilderman, 2010).

Building design in this approach is standard and rigid (Tambe et al., 2018; Ahmed, 2011); which means that the livelihood and needs of different families are not taken into consideration (Carrasco, Ochiai \& Okazaki, 2018; Sina et al., 2018; Oliver-Smith \& De Sherbinin, 2014). Hence, the reconstructed houses by contractors can be deviated from the beneficiaries' lifestyle and culture (Samaddar et al., 2016; Barenstein, 2015). Moreover, finding an appropriate site can be a major challenge in ADRRS (Bilau, Witt \& Lill, 2015; Danquah, Attippoe \& Ankrah, 2014; Hidayat \& Egbu, 2010). If available, the new reconstruction site should be developed prior to the reconstruction, which means that considerable time and money will be spent on land development (Chang et al., 2010; Karunasena \& Rameezdeen, 2010). Besides, the transfer of a community to another location can result in the destruction of social networks and reduction of members' livelihood opportunities (Fayazi \& Lizarralde, 2019; Carrasco, Ochiai \& Okazaki, 2018).

In ADRRS approach, all building materials were exported from the outside (Sina et al., 2018; Barenstein \& Iyenger, 2010); which affect the transportation costs for residents (Fayazi \& Lizarralde, 2019). Therefore, ADRRS may lead to the more expensive housing reconstruction (Tambe et al., 2018; Lyons, 2009). In some cases, materials and technology used for construction were not appropriate to people's cultural sensitivities or the local weather (Bilau, Witt \& Lill, 2015). Moreover, the future housing extensions in ADRRS is forbidden (Carrasco, Ochiai \& Okazaki, 2016). The quality of reconstruction in ADRRS depends mainly on the contractor experience in reconstruction (Karunasena \& Rameezdeen, 2010, Lyons, 2009). In the same time, agencies in ADRRS do not always have time to supervise the construction process, which may lead to corruption (Jha et al., 2010). Additionally, there is no sufficient transparency and accountability in ADRRD (Carrasco \& O'Brien, 2018). Hence, the quality of housing reconstruction is poor (Tambe et al., 2018; Danquah, Attippoe \& Ankrah, 2014). These factors may result in housing beneficiaries of ADRRD programs to being dissatisfied (Tambe et al., 2018; Barenstein, 2015). Consequently, ADRRD approach would produce low occupancy rates (Samaddar et al., 2016; Danquah, Attippoe \& Ankrah, 2014).

\section{Factors Affecting the Choice of Resourcing Approach}

After presenting the different resourcing approaches of PDHR in the previous section, this section overviews the factors that significantly determine the most suited approach to be used after a disaster. Chang et al. (2011) demonstrated that identifying the most suitable and applicable approach is one of the complex tasks after disaster. It is of utmost importance to provide better assistance to victims and to avoid possible future vulnerabilities and build back better (Karunasena \& Rameezdeen, 2010; Lizarralde et al., 2010; Lyons et al., 2010). However, Barakat (2003) stated that there is no definitively right or wrong approach, but there will be a choice which will be more likely than others to achieve the desired aims and to fulfil the needs of the communities.

The choice of the best resourcing approach will depend on the skills and capacity of the beneficiaries, the availability of local material, the complexity of the housing design and type of construction, the timescale for 
reconstruction and the availability of funding (Ophiyandri, 2013). Barakat (2003) mentioned other factors affecting the choice of resourcing approach like: the scale and spread of destruction and the size of the settlement; the technical skills of households, capacities of the stakeholders (technical, economic, organizational); the amount of time and effort the target population is willing to invest in the reconstruction; and the timeframe of the project. The selection of a resourcing approach to be adopted should consider factors such as reconstruction costs; improvement in physical and social safety; restoration of livelihoods; and communities' goals (Jha et al. 2010; Karunasena \& Rameezdeen 2010). The most suitable approach should be locally assessed and principally relates to the degree of household control over the project (Enshassi et al., 2017a).

\section{Factors Affecting the Success of Resourcing Approaches}

This section identifies and analyzes the factors listed by previous authors to identify the most critical factors affecting the success of resourcing approaches. Karunasena \& Rameezdeen (2010) used the beneficiary satisfaction as to compare between the success of different resourcing approaches. They used the beneficiary satisfaction to measure the success though different items including: Durability of house; Aesthetics and appearance; Functionality; Space availability; Incorporation of beneficiary requirements at the design stage; Flexibility to make changes in future; Location of the house; Size of land; Overall facilities provided in the reconstructed house; and Response time. Table (1) listed twenty-three factors which are collected from different literatures and their citation frequency are determined. Then these factors are prioritized according to their frequencies in literatures as shown in Table (1). These factors can be considered as a guide for reconstruction stakeholder to compare between different resourcing approaches. Stakeholders can also employ them to identify the success level of a resourcing approach adopted after a particular disaster.

Table 1- Prioritization of the factors determine the success of resourcing approach

\begin{tabular}{|c|c|c|c|c|}
\hline No. & $\begin{array}{l}\text { Factors determine the success } \\
\text { of resourcing approach }\end{array}$ & Authors & $\begin{array}{l}\text { Frequency } \\
\text { of citation }\end{array}$ & Rank \\
\hline 1. & Reconstruction quality & $\begin{array}{l}\text { Tambe et al., 2018; Carrasco, Ochiai \& Okazaki, } \\
\text { 2016; Kingham, Dionisio \& Newman, 2016; } \\
\text { Samaddar et al., 2016; Bilau, Witt \& Lill, 2015; } \\
\text { Ophiyandri, Amaratunga \& Keraminiyage, 2015; } \\
\text { Andrew et al., 2013; Barenstein, 2012; Ahmed, 2011 }\end{array}$ & 9 & 1 \\
\hline 2. & Reconstruction duration & $\begin{array}{l}\text { Tambe et al., 2018; Hussain, 2017; Vahanvati \& } \\
\text { Beza, 2017; Santiago et al., 2017; Bilau \& Witt, } \\
\text { 2016; Samaddar et al., 2016; Bilau, Witt \& Lill, } \\
\text { 2015; Ophiyandri, Amaratunga \& Keraminiyage, } \\
\text { 2015 }\end{array}$ & 8 & 2 \\
\hline 3. & $\begin{array}{l}\text { Overall beneficiaries' } \\
\text { satisfaction } \quad \text { of } \\
\text { reconstructed houses }\end{array}$ & $\begin{array}{l}\text { Arlikatti et al., 2018; Tambe et al., 2018; Enshassi et } \\
\text { al., 2017a; Vahanvati \& Beza, 2017; Samaddar et al., } \\
\text { 2016; Barenstein, 2015; Bilau, Witt \& Lill, 2015; } \\
\text { Tafti \& Tomlinson, 2015 }\end{array}$ & 8 & 2 \\
\hline 4. & $\begin{array}{l}\text { The prioritization and } \\
\text { articulation of needs are in the } \\
\text { hands of the affected families } \\
\text { (Functionality) }\end{array}$ & $\begin{array}{l}\text { Carrasco, Ochiai \& Okazaki, 2018; Sina et al., 2018; } \\
\text { Samaddar et al., 2016; Sharma, 2018; Bothara et al., } \\
\text { 2016; Sadiqi, Trigunarsyah \& Coffey, 2016; Bilau, } \\
\text { Witt \& Lill, 2015; Ophiyandri, Amaratunga \& } \\
\text { Keraminiyage, 2015 }\end{array}$ & 8 & 2 \\
\hline 5. & House location & $\begin{array}{l}\text { Sharma, 2018; Santiago et al., 2017; Samaddar et al., } \\
\text { 2016; Bilau \& Witt, 2016; Hsu et al., 2015; Danquah, } \\
\text { Attippoe \& Ankrah, 2014; Andrew et al., } 2013\end{array}$ & 8 & 2 \\
\hline 6. & $\begin{array}{l}\text { Preserve the community culture } \\
\text { in reconstruction }\end{array}$ & $\begin{array}{l}\text { Bothara et al., 2016; Samaddar et al., 2016; } \\
\text { Barenstein, 2015; Bilau, Witt \& Lill, 2015; Danquah, } \\
\text { Attippoe \& Ankrah, 2014; Andrew et al., 2013; Jha et } \\
\text { al., 2010; } \\
\text { Lankatilleke, 2010, }\end{array}$ & 8 & 2 \\
\hline 7. & $\begin{array}{l}\text { Availability of strict monitoring } \\
\text { mechanism }\end{array}$ & $\begin{array}{l}\text { Fayazi \& Lizarralde, 2019; Enshassi et al., 2017a; } \\
\text { Alam, 2010; IFRC, 2010; Jha et al., 2010; } \\
\text { Karunasena \& Rameezdeen, 2010; Kovács, } \\
\text { Matopoulos \& Hayes, 2010; Barakat, 2003 }\end{array}$ & 8 & 2 \\
\hline 8. & $\begin{array}{l}\text { Beneficiary participation in } \\
\text { decision making }\end{array}$ & $\begin{array}{l}\text { Fayazi \& Lizarralde, 2019; Carrasco \& O’Brien, } \\
\text { 2018; Carrasco, Ochiai \& Okazaki, 2018; Tambe et } \\
\text { al., 2018; Sitorus et al., 2017; Bothara et al., 2016; } \\
\text { Kingham, Dionisio \& Newman, 2016; Samaddar et } \\
\text { al., 2016 }\end{array}$ & 8 & 2 \\
\hline 9. & $\begin{array}{l}\text { Flexibility to modify house } \\
\text { design }\end{array}$ & $\begin{array}{l}\text { Tambe et al., 2018; Danquah, Attippoe \& Ankrah, } \\
\text { 2014; Barenstein, 2012; Ahmed, 2011; Da Silva \& } \\
\text { Batchelor, 2010; Jha et al., 2010; Schilderman, } 2010\end{array}$ & 7 & 3 \\
\hline 10 . & House design & Sharma, 2018; Andrew et al., 2013; Lyons, 2009; & 6 & 4 \\
\hline
\end{tabular}


Table 1- Prioritization of the factors determine the success of resourcing approach

\begin{tabular}{|c|c|c|c|c|}
\hline No. & $\begin{array}{l}\text { Factors determine the success } \\
\text { of resourcing approach }\end{array}$ & Authors & $\begin{array}{l}\text { Frequency } \\
\text { of citation }\end{array}$ & Rank \\
\hline 11. & $\begin{array}{l}\text { Adequate technical supervision } \\
\text { of the supervising party }\end{array}$ & $\begin{array}{l}\text { Ratnayake \& Rameezdeen 2008; Barenstein, } 2006 \\
\text { Fayazi \& Lizarralde, 2019; Tambe et al., 2018; Bilau } \\
\text { \& Witt, 2016; Arroyo, 2015; Davis \& Alexander, } \\
2015\end{array}$ & 6 & 4 \\
\hline 12. & $\begin{array}{l}\text { Sufficient value of } \\
\text { reconstruction fund }\end{array}$ & $\begin{array}{l}\text { Fayazi \& Lizarralde, 2019; Tambe et al., 2018; } \\
\text { Hussain, 2017; Santiago et al., 2017; Vahanvati \& } \\
\text { Beza, 2017; Samaddar et al., 2016 }\end{array}$ & 6 & 4 \\
\hline 13. & $\begin{array}{l}\text { Flexibility to incorporate } \\
\text { extensions to the house in } \\
\text { future }\end{array}$ & $\begin{array}{l}\text { Carrasco, Ochiai \& Okazaki, 2016; Da Silva \& } \\
\text { Batchelor, 2010; Karunasena \& Rameezdeen, 2010; } \\
\text { Dasgupta \& Beard, 2007; Pyles, } 2007\end{array}$ & 5 & 5 \\
\hline 14. & $\begin{array}{lcr}\text { Availability } & \text { of standard } \\
\text { specifications, } & \text { staff } & \text { with } \\
\text { technical expertise } & \text { and } \\
\text { specialist } & \text { skills } & \text { in } \\
\text { reconstruction } & & \end{array}$ & $\begin{array}{l}\text { Bilau \& Witt, 2016; Da Silva \& Batchelor, 2010; } \\
\text { Barenstein, 2006; Barenstein et al., 2005; Barakat, } \\
2003\end{array}$ & 5 & 5 \\
\hline 15 . & Houses size & $\begin{array}{l}\text { Karunasena \& Rameezdeen, 2010; Barenstein et al., } \\
2005\end{array}$ & 2 & 6 \\
\hline 16. & $\begin{array}{l}\text { Procedure of transferring } \\
\text { installments to beneficiaries }\end{array}$ & Samaddar et al., 2016; Boano, 2009 & 2 & 7 \\
\hline 17. & $\begin{array}{l}\text { Adjustment of assistance } \\
\text { according to needs of the } \\
\text { household }\end{array}$ & Enshassi \& Zaiter, 2013; Jha et al., 2010 & 2 & 7 \\
\hline 18. & $\begin{array}{l}\text { Feeling safe from future } \\
\text { disaster }\end{array}$ & Bilau \& Witt, 2016 & 1 & 8 \\
\hline 19. & $\begin{array}{l}\text { Allowance of incremental } \\
\text { reconstruction }\end{array}$ & Lawther, 2009 & 1 & 8 \\
\hline 20. & $\begin{array}{l}\text { Accessibility to infrastructures } \\
\text { such as roads, schools, a } \\
\text { community hall, a water supply } \\
\text { system and drainage canals }\end{array}$ & Barenstein, 2006 & 1 & 8 \\
\hline 21. & $\begin{array}{l}\text { Equity of distribution financial } \\
\text { and technical assistance }\end{array}$ & Lankatilleke, 2010 & 1 & 8 \\
\hline 22. & $\begin{array}{l}\text { The start-up time of } \\
\text { reconstruction after disaster }\end{array}$ & Alam, 2010 & 1 & 8 \\
\hline
\end{tabular}

\section{Conclusion}

Resource availability is a key contributory factor to a successful project of post disaster housing reconstruction. This study reviewed the literature to highlight the resourcing approaches of PDHR with their features, advantages and disadvantages. The classification of resourcing approaches adopted in this study is related to the World Bank classification. These approaches are owner driven reconstruction, cash based reconstruction, community driven reconstruction, agency driven reconstruction in situ and agency driven reconstruction in relocation site. The previous experiences of PDHR proved that the owner driven reconstruction approach was the most successful approach to reconstruct houses in post disasters. However, agency driven reconstruction approach was the most used after disaster around the world. This study also presented the factors affecting the choice of the most suited resourcing approach after a particular disaster with overviewing twenty-three factors influencing the success of resourcing approaches. Reconstruction quality was considered as the most significant factor that affect the success of resourcing approaches. The most cited factors reported in this study can be used as a guide to reconstruction practitioner to choose the most appropriate resourcing approach to reconstruct houses after disasters.

\section{Acknowledgement}

Thanks and appreciation is due to AvH Foundation for sponsoring and financing this research and for the continuous support and encouragement.

\section{References}

Ahmed, I. (2011). An overview of post-disaster permanent housing reconstruction in developing countries. International Journal of Disaster Resilience in the Built Environment, 2(2), 148164, https://doi.org/10.1108/17595901111149141

Alam, K. (2010). Bangladesh: Can large actors overcome the absence of state will? Building Back Better, 241-261 
Alston, M., Hargreaves, D., \& Hazeleger, T. (2018). Post disaster Social Work: Reflections on the Nature of Place and Loss. Australian Social Work, 1-12, https://doi.org/10.1080/0312407X.2017.1409776

Andrew, S., Arlikatti, S., Long, L., \& Kendra, J. (2013). The effect of housing assistance arrangements on household recovery: an empirical test of donor-assisted and owner-driven approaches. Journal of Housing and the Built Environment, 28(1), 17-34, https://doi.org/10.1007/s10901-012-9266-9

Arlikatti, S., Maghelal, P., Agnimitra, N., \& Chatterjee, V. (2018). Should I stay or should I go? Mitigation strategies for flash flooding in India. International journal of disaster risk reduction, 27, 48-56, https://doi.org/10.1016/j.ijdrr.2017.09.019.

Arroyo, I. (2015). Building Resilience through Housing Reconstruction in Areas Affected by Typhoon Haiyan1 in the Philippines: Users Involvement and Incremental Growth for Medium-rise Buildings. OPPORTUNITIES, $67-93$.

Arslan, H., \& Johnson, C. (2010). Turkey: Can small actors overcome the absence of state will?. Building Back Better, 263- 283.

Arslan, H., \& Unlu, A. (2006). The evaluation of community participation in housing reconstruction projects after Duzce earthquake. In 2006 International Conference and Student Competition on post-disaster reconstruction, Florence, Italy, 1-13, http://www.grif.umontreal.ca/pages/ARSLAN_\%20Hakan.pdf

Asfour, O., \& Zourob, N. (2017). The neighborhood unit adequacy: An analysis of the case of Gaza, Palestine. Cities, 69, 1-11, https://doi.org/10.1016/j.cities.2017.05.014

Aubrey, D. (2010). Kenya: Can temporary shelter contribute to participatory reconstruction?. Building Back Better, 215- 240.

Ballesteros, M., \& Egana, J. (2013). Efficiency and effectiveness review of the National Housing Authority (NHA) resettlement program. PIDS Discussion Paper Series, 28, Philippine Institute for Development Studies (PIDS), Philippines, http://hdl.handle.net/10419/126958

Barakat, S. (2003). Housing reconstruction after conflict and disaster. Humanitarian Policy Group, Network Papers, 43, 1-40, https://odihpn.org/wp-content/uploads/2004/02/networkpaper043.pdf.

Barakat, S. (2009). The failed promise of multi-donor trust funds: aid financing as an impediment to effective statebuilding in post-conflict contexts. Policy studies, 30(2), 107-126, https://doi.org/10.1080/01442870902723485

Barakat, S., \& Shaban, O. (2015). Back to Gaza: A new approach to reconstruction. Brookings Doha Centre, Doha, Qatar. Available at: https://www.brookings.edu/wp-content/uploads/2016/06/English-PDF-2.pdf.

Barenstein, J. (2006). Housing reconstruction in post-earthquake Gujarat. A comparative analysis. HPN paper, 54, 138.

Barenstein, J. (2012). The Role of Communities in Post Disaster Reconstruction. A call for owner driven approaches. Tafter Journal, 50, 1-12.

Barenstein, J. (2015). Continuity and change in housing and settlement patterns in post-earthquake Gujarat, India. International Journal of Disaster Resilience in the Built Environment, 6(2), 140155, https://doi.org/10.1108/IJDRBE-01-2014-0009.

Barenstein, J., \& Iyengar, S. (2010). India: From a culture of housing to a philosophy of reconstruction. Building Back Better, 163- 188 .

Barenstein, J., \& Pittet, D. (2007). Post disaster housing reconstruction Current trends and sustainable alternatives for tsunami-affected communities in coastal Tamil Nadu. Institute for Applied Sustainability to the Built Environment, University of Applied Sciences of Southern Switzerland, Canobbio, 1-44, http://www.chs.ubc.ca/archives/files/PostDisaster\%20housing\%20recounstruction\%20current $\% 20$ trends\%20and\%20sustianable\%20alternatives.pdf. 
Barenstein, J., Joshi, V., Shinde, S., Vyas, S., \& Jadeja, Y. (2005). Comparative Analysis of Six Housing Reconstruction Approaches in Post-Earthquake Gujarat Report, Sculoa Univeritaria Professionale della Svizzera Italiana, Lugano, Switzerland

Bessant, J. (2015). Report of Case Study: Cash-Based Programming (CBP) in the Food Assistance Sector, Centre for Research in Innovation Management, University of Brighton, UK

Bilau, A., \& Witt, E. (2016). An analysis of issues for the management of post-disaster housing reconstruction. International Journal of Strategic Property Management, 20(3), 265-276, doi:10.3846/1648715X.2016.1189975.

Bilau, A., Witt, E., \& Lill, I. (2015). A framework for managing post-disaster housing reconstruction. Procedia economics and finance, 21, 313-320, https://doi.org/10.1016/S2212-5671(15)00182-3.

Boano, C. (2009). Housing anxiety and multiple geographies in post- tsunami Sri Lanka. Disasters, 33(4), 762-785, https://doi.org/10.1111/j.1467-7717.2009.01108.x.

Boen, T. (2008). Reconstruction of houses in Aceh, three years after the December 26, 2004 tsunami. In International Conference on Earthquake Engineering and Disaster Mitigation, Jakarta, Indonesia, 1-7.

Bothara, J., Dhakal, R., Dizhur, D., \& Ingham, J. (2016). The Challenges of Housing Reconstruction after the April 2015 Gorkha, Nepal Earthquake. Technical Journal of Nepal Engineers' Association, 1, 121-134

Brück, T., d'Errico, M., \& Pietrelli, R. (2018). The effects of violent conflict on household resilience and food security: Evidence from the 2014 Gaza conflict. World Development, 1-21, https://doi.org/10.1016/j.worlddev.2018.05.008

Butt, K., \& Butt, A. (2016). Blockade on Gaza Strip: A Living Hell on Earth. Journal of Political Studies, 23(1), 157182

Carrasco, S., \& O'Brien, D. (2018). The Role of Humanitarian Agencies in Reconstruction and Development of Disaster Affected Communities in Japan and the Philippines. Procedia engineering, 212, 606-613

Carrasco, S., Ochiai, C., \& Okazaki, K. (2016). Impacts of resident-initiated housing modifications in resettlement sites in Cagayan de Oro, Philippines. International journal of disaster risk reduction, 17, 100-113, https://doi.org/10.1016/j.ijdrr.2016.05.001

Carrasco, S., Ochiai, C., \& Okazaki, K. (2018). Resident-built housing modifications as a factor of adaptability to the built environment in disaster-induced resettlement site in Cagayan de Oro, Philippines. In Science and Technology in Disaster Risk Reduction in Asia, 26, 453-474, https://doi.org/10.1016/B978-0-12-812711-7.00026-2

Chang, A. (2012). Resourcing for post-disaster housing reconstruction. Unpublished Doctoral dissertation, The University of Auckland, New Zealand

Chang, Y., Wilkinson, S., Brunsdon, D., Seville, E., \& Potangaroa, R. (2011). An integrated approach: managing resources for post- disaster reconstruction. Disasters, 35(4), 739-765, https://doi.org/10.1111/j.14677717.2011.01240.x

Chang, Y., Wilkinson, S., Potangaroa, R., \& Seville, E. (2010). Resourcing challenges for post-disaster housing reconstruction: a comparative analysis. Building Research \& Information, 38(3), 247-264, https://doi.org/10.1080/09613211003693945

Chang, Y., Wilkinson, S., Potangaroa, R., \& Seville, E. (2012a). Managing resources in disaster recovery projects. Engineering, Construction and Architectural Management, 19(5), 557-580, https://doi.org/10.1108/09699981211259621

Chang, Y., Wilkinson, S., Potangaroa, R., \& Seville, E. (2012b). Resourcing for post-disaster reconstruction: a comparative study of Indonesia and China. Disaster Prevention and Management: An International Journal, 21(1), 7 21, https://doi.org/10.1108/09653561211202674 
Chen, L., Liu, Y., \& Chan, K. (2006). Integrated community-based disaster management program in Taiwan: a case study of Shang-An village. Natural Hazards, 37(1-2), 209-223 https://doi.org/10.1007/s11069-005-4669-5

Da Silva, J., \& Batchelor, V. (2010). Indonesia: Understanding agency policy in a national context. Building back better, 135- 161

Daly, P., \& Brassard, C. (2011). Aid accountability and participatory approaches in post-disaster housing reconstruction 1. Asian Journal of Social Science, 39(4), 508-533, https://doi.org/10.1163/156853111X597305

Danquah, J., Attippoe, J., \& Ankrah, J. (2014). Assessment of residential satisfaction in the resettlement towns of the Keta basin in Ghana. International Journal Civil Engineering, Construction and Estate Management, 2(3), 26-45

Dasgupta, A., \& Beard, V. (2007). Community driven development, collective action and elite capture in Indonesia. Development and change, 38(2), 229-249, https://doi.org/10.1111/j.1467-7660.2007.00410.x.

Davidson, C., Johnson, C., Lizarralde, G., Dikmen, N., \& Sliwinski, A. (2007). Truths and myths about community participation in post-disaster housing projects. Habitat international, 31(1), 100-115, https://doi.org/10.1016/j.habitatint.2006.08.003.

Davis, I., \& Alexander, D. (2015). Recovery from disaster. Abingdon, New York: Routledge, https://doi.org/10.4324/9781315679808

Enshassi, A., Shakalaih, S., and Mohamed, S. (2019). Success factors for community participation in the pre-disaster phase, paper published in the Proceedings of the Sustainable Built Environment Conference 2019 (SBE19 Tokyo), Tokyo, Japan.

Enshassi, A., Shakalaih, S. and Alkilani, S. (2018) Strategies for community participation in pre-disaster phase, Journal of Construction in Developing Countries 23(2), 107-127.

Enshassi, A. and Shakalaih, S. (2016). Community based disaster risk reduction: a case study from the Gaza Strip, Proceedings of the 2nd International Conference on Disaster Management \& Civil Engineering, (ICDMCE 2016), Kyoto, Japan. April. 2016

Enshassi, A., Shakalaih, S. and Arain, F. (2017b). Community participation challenges in pre-disaster phase within non-governmental organizations, International Journal of Construction Project Management, 9(2), 111-124.

Enshassi, A., Chatat, T., Meding, J., \& Forino, G. (2017a). Factors influencing post-disaster reconstruction project management for housing provision in the Gaza Strip, Occupied Palestinian Territories. International Journal of Disaster Risk Science, 8(4), 402-414 https://doi.org/10.1007/s13753-017-0155-4

Enshassi, A. and Shatat, T, (2012), Post disaster housing damage assessment in the Gaza Strip-Palestine, Proceedings of the 37 IAHS World Congress, April 16-19, Istanbul, Turkey, pp. 755-763

Fayazi, M., \& Lizarralde, G. (2019). The Impact of Post-Disaster Housing Reconstruction Policies on Different Beneficiary Groups: The Case of Bam, Iran. In Resettlement Challenges for Displaced Populations and Refugees, Springer, Cham, 123-140, https://doi.org/10.1007/978-3-319-92498-49

He, F., \& Zhuang, J. (2016). Balancing pre-disaster preparedness and post-disaster relief. European Journal of Operational Research, 252(1), 246-256, https://doi.org/10.1016/j.ejor.2015.12.048

Hidayat, B., \& Egbu, C. (2010). A literature review of the role of project management in post-disaster reconstruction. In Procs 26th Annual ARCOM Conference, Leeds, UK, 1269-1278, http://usir.salford.ac.uk/id/eprint/10144

Hidellage, V., \& Usoof, A. (2010). Scaling-up people-centred reconstruction: Lessons from Sri Lanka's post-tsunami owner-driven program. Building Back Better, 77- 112

Hsu, M., Howitt, R., \& Miller, F. (2015). Procedural vulnerability and institutional capacity deficits in post-disaster recovery and reconstruction: Insights from Wutai Rukai experiences of Typhoon Morakot. Human Organization, 74(4), 308-318, https://doi.org/10.17730/0018-7259-74.4.308 
Hussain, L. (2017). Post Disaster Housing Reconstruction: A Study of the Government of Pakistan's Housing Reconstruction Program in Azad Jammu \& Kashmir after October 2005 Earthquake. Unpublished Doctoral dissertation, Durham University, England

Ingirige, B., Haigh, R., Malalgoda, C., \& Palliyaguru, R. (2008). Exploring good practice knowledge transfer related to post tsunami housing re-construction in Sri Lanka. Journal of construction in developing countries, 13(2), 21-42, http://eprints.hud.ac.uk/id/eprint/22595

International Federal of Red Cross and Red Crescent Societies (2010). Owner driven housing reconstruction guidelines, Geneva, Switzerland.

Islam, M., Kolade, O., \& Kibreab, G. (2018). Post- disaster Housing Reconstruction: The Impact of Resourcing in Post- cyclones Sidr and Aila in Bangladesh. Journal of International Development, 30, 934-960, https://doi.org/10.1002/jid.3367

Istijono, B., \& Ophiyandri, T. (2015). Community-Based Approach in A Small Scale Irrigation Project in Indonesia: Ways and Advantages. Civil Engineering Dimension, 17(2), 95-100, https://doi.org/10.9744/ced.17.2.95-100

Jha, A., Barenstein, J., Phelps, P., Pittet, D., \& Sena, S. (2010). Safer homes, stronger communities: a handbook for reconstructing after natural disasters. The World Bank, Washington

Karunasena, G., \& Rameezdeen, R. (2010). Post-disaster housing reconstruction: Comparative study of donor vs owner-driven approaches. International Journal of Disaster Resilience in the Built Environment, 1(2), 173-191, https://doi.org/10.1108/17595901011056631

Kingham, S., Dionisio, M., \& Newman, P. (2016). The right tools at the right time: Encouraging community involvement in the post-disaster reconstruction of Christchurch, New Zealand. In proceeding of IGU Urban Commission Annual Conference, University College Dublin, Ireland, 4-11

Kovács, G., Matopoulos, A., \& Hayes, O. (2010). A community-based approach to supply chain design. International Journal of Logistics: Research and Applications, 13(5), 411-422, https://doi.org/10.1080/13675567.2010.511609.

Lankatilleke, L. (2010). The people's process: The viability of an international approach. Building Back Better, $63-73$.

Lawther, P. (2009). Community involvement in post disaster re- construction- case study of the British Red Cross Maldives recovery program. International Journal of Strategic Property Management, 13(2), 153-169, https://doi.org/10.3846/1648-715X.2009.13.153-169

Leersum, A., \& Arora, S. (2011). Implementing seismic-resistant technologies in post-earthquake Pakistan: A process analysis of owner driven reconstruction. Habitat International, 35(2), 254-264, https://doi.org/10.1016/j.habitatint.2010.09.009

Leitmann, J. (2007). Cities and calamities: learning from post-disaster response in Indonesia. Journal of Urban Health, 84(1), 144-153, https://doi.org/10.1007/s11524-007-9182-6

Lizarralde, G. (2010). Decentralizing (re) construction: Agriculture cooperatives as a vehicle for reconstruction in Colombia. Building Back Better: Delivering people-centered housing reconstruction at scale, Practical Action Publishing Ltd, Warwickshire, UK, 191-214.

Lu, Y., \& Xu, J. (2014). NGO collaboration in community post- disaster reconstruction: field research following the 2008 Wenchuan earthquake in China. Disasters, 39(2), 258-278, https://doi:10.1111/disa.12098

Lyons, M. (2009). Building back better: the large-scale impact of small-scale approaches to reconstruction. World Development, 37(2), 385-398, https://doi.org/10.1016/j.worlddev.2008.01.006

Lyons, M. (2010). Can large-scale participation be people-centered? Evaluating reconstruction as development. Building Back Better, 39-61 
Maly, E. (2018). Building back better with people centered housing recovery. International Journal of Disaster Risk Reduction, 29, 84-93, https://doi.org/10.1016/j.ijdrr.2017.09.005

Mulligan, M. (2015). On ambivalence and hope in the restless search for community: How to work with the idea of community in the global age. Sociology, 49(2), 340-355, https://doi.org/10.1177/0038038514534008

Oliver-Smith, A., \& de Sherbinin, A. (2014). Resettlement in the twenty-first century. Forced Migration Review, (45), $23-25$

Omidvar, B., Zafari, H., \& Derakhshan, S. (2010). Reconstruction management policies in residential and commercial sectors after the 2003 bam earthquake in Iran. Natural Hazards, 54(2), 289-306, https://doi.org/10.1007/s11069-0099468-y

Ophiyandri, T. (2013). Project risk management for community-based post-disaster housing reconstruction, Unpublished Doctoral dissertation, University of Salford, UK, http://usir.salford.ac.uk/id/eprint/30661

Ophiyandri, T., Amaratunga, D., \& Keraminiyage, K. (2015). Advantages and limitations of community-based postdisaster housing reconstruction projects. International Journal of Disaster Resilience in the Built Environment, 7(4), 420-431, https://doi.org/10.1108/IJDRBE-08-2014-0066

Ophiyandri, T., Amaratunga, D., Pathirage, C., \& Keraminiyage, K. (2013). Critical success factors for communitybased post-disaster housing reconstruction projects in the pre-construction stage in Indonesia. International Journal of Disaster Resilience in the Built Environment, 4(2), 236-249, https://doi.org/10.1108/IJDRBE-03-2013-0005

Ophiyandri, T., Amaratunga, R., \& Pathirage, C. (2010). Community based post disaster housing reconstruction: Indonesian perspective, International Journal of Disaster Resilience in the Built Environment, 1-17, http://usir.salford.ac.uk/id/eprint/9761

Pyles, L. (2007). Community organizing for post-disaster social development: Locating social work. International social work, 50(3), 321-333, https://doi.org/10.1177/0020872807076044

Quzai, U. (2010). Pakistan: Implementing people-centred reconstruction in urban and rural areas. Building Back Better, $113-134$

Ratnayake, R., \& Rameezdeen, R. (2008). Post disaster housing reconstruction: Comparative study of donor driven vs. owner driven approach. Building Resilience, 1067, 51-62

Roosli, R., Nordin, J., \& O’Brien, G. (2018). The Evaluation of Community Participation in Post-Disaster Housing Reconstruction Projects in Malaysia. Procedia engineering, 212, 667-674, https://doi.org/10.1016/j.proeng.2018.01.086

Sadiqi, Z., Trigunarsyah, B., \& Coffey, V. (2016). A framework for community participation in post-disaster housing reconstruction projects: A case of Afghanistan. International Journal of Project Management, 35(5), 900-912, https://doi.org/10.1016/j.ijproman.2016.11.008

Samaddar, S., Okada, N., Choi, J., \& Tatano, H. (2016). What constitutes successful participatory disaster risk management? Insights from post-earthquake reconstruction work in rural Gujarat, India. Natural Hazards, 85(1), 111138, https://doi.org/10.1007/s11069-016-2564-X

Santiago, J., Manuela Jr, W., Tan, M., Saňez, S., \& Tong, A. (2017). Agency-driven post-disaster recovery: A comparative study of three Typhoon Washi resettlement communities in the Philippines. International journal of disaster risk reduction, 27, 480-489, https://doi.org/10.1016/j.ijdrr.2017.11.012

Schilderman, T. (2010). Putting people at the center of reconstruction. Building Back Better, 7-37

Shafique, K., \& Warren, C. (2016). Stakeholders and Their Significance in Post Natural Disaster Reconstruction Projects: A Systematic Review of the Literature. Asian Social Science, 12(10), 1-17, https://doi.org/10.5539/ass.v12n10p1 
Sharma, V. (2018). Building back better: Focus on resilience and participation. In Science and Technology in Disaster Risk Reduction in Asia, 395-408, https://doi.org/10.1016/B978-0-12-812711-7.00023-7.

Sina, D., Chang-Richards, A., Wilkinson, S., \& Potangaroa, R. (2018). What does the future hold for relocated communities' post-disaster? Factors affecting livelihood resilience. International Journal of Disaster Risk Reduction, 1-38, https://doi.org/10.1016/j.ijdrr.2018.11.015.

Sitorus, Y. (2017). Community Driven Development in Traditional Communities In Papua. Journal of Regional and City Planning, 28(1), 16-31, http://journals.itb.ac.id/index.php/jpwk/article/view/2261.

Tafti, M., \& Tomlinson, R. (2015). Best practice post-disaster housing and livelihood recovery interventions: winners and losers. International Development Planning Review, 37(2), 165-185, https://doi.org/10.3828/idpr.2015.14.

Tambe, S., Pradhan, S., Donka, P., \& Singh, P. (2018). Post-earthquake housing reconstruction in the Sikkim Himalaya: approaches, challenges, and lessons learnt. Development in Practice, 28(5), 647-660, https://doi.org/10.1080/09614524.2018.1469601.

Thurairajah, N. (2013). Empowering women during post disaster reconstruction. Unpublished Doctoral dissertation, University of Salford, United Kingdom, http://usir.salford.ac.uk/id/eprint/30683.

Vahanvati, M. (2017). Owner-driven housing reconstruction as a means of enhancing disaster resilience of at-risk communities in India. Unpublished PhD Thesis, RMIT University, Melbourne, Victoria

Vahanvati, M., \& Beza, B. (2017). An owner-driven reconstruction in Bihar. International Journal of Disaster Resilience in the Built Environment, 8(3), 306-319, https://doi.org/10.1108/IJDRBE-10-2015-0051.

Vahanvati, M., \& Mulligan, M. (2017). A new model for effective post-disaster housing reconstruction: Lessons from Gujarat and Bihar in India. International Journal of Project Management,35(5), 802-817, https://doi.org/10.1016/j.ijproman.2017.02.002.

Wilkinson, S., Chang-Richards, A., Seville, E., \& Brunsdon, D. (2014). Assisting Self-Managing Rebuilding Owners in New Zealand to Rebuild their Homes: Lessons for New Zealand from the 2009 Victoria Bush Fire Recovery. Resilient Organizations Bulletin, 2, 1-5, http://hdl.handle.net/10092/10963 